\title{
In silico identification of cis-Regulatory elements and their functional annotations from assembled ESTs of Artemisia annua $L$. involved in abiotic stress signaling
}

\author{
PRAVEJ ALAM ${ }^{1 *}$, THAMER AL BALAWI ${ }^{1}$ \\ ${ }^{1}$ Department of Biology, College of Science and Humanities in Al-Kharj, Prince Sattam bin \\ Abdulaziz University, 11942, Saudi Arabia
}

\begin{abstract}
Salt stress is a common side-effect in plants impacted on plant growth, metabolism and productivity. A. апnиa L. is one of the well-known antimalarial plants, biosynthesized artemisinin in its leaf, now introduced in all-over the world. In this article, we have analyzed the A. аппиа L. ESTs under salt stress and predicted cis-regulatory elements, roles in abiotic stress signaling. Further, the predicted abiotic stress responsive factors were analyzed in order to their function annotations as compare to the genome of Arabidopsis thaliana. 11 EST-contigs assembled from 127 were 29 signals elements were identified by CAP3 program. In order to evaluate accuracy of the identified factors, gene ontology functions were performed. GOBP analysis enriched the genes $(85.71 \%)$ as the response to abiotic signaling. The co-expression analysis was revealed by gene investigators and String 10.0, these factors-oriented genes had at least 0.40 correlations and 0.7 mutual connection. In projected PPI network, the recognized factors belong to plant hormone signaling and diterpene pathways. These factors (ABF1, APX CCC1, CPK6, JAZ1, MYC2) introduced as candidate genes responsive factors could be overexpressed in A. апnиa L. plants either alone or in a shuttle may led the good metabolism and higher artemisinin content.
\end{abstract}

Keywords Artemisinin, ESTs, salt stress, cis-regulatory elements, GOBP, Co-Expression.

To cite this article: ALAM P, BALAWI AT. In silico identification of Cis-Regulatory elements and their functional annotations from assembled ests of artemisia Annua L. involved in abiotic stress signaling. Rom Biotechnol Lett. 2021; 26(2): 2384-2395. DOI: $10.25083 / \mathrm{rbl} / 26.2 / 2384.2395$

*Corresponding author: PRAVEJ ALAM, Department of Biology, College of Science and Humanities, Prince Sattam bin Abdulaziz University, 11942, Al-Kharj, Kingdom of Saudi Arabia (KSA)

E-mail: alamprez@gmail.com; ps.alam@psau.edu.sa 


\section{Introduction}

The plant growth is stunted by wide spectrum of abiotic (Salinity, drought heavy metals) and biotic factors (Fungus, bacteria; JENKS and HASEGAWA, 2005). Due to stress conditions especially abiotic, $50 \%$ crop productivity loss in recent past (HAGGAG et al, 2015; PELEG et al, 2011). The abiotic stress responses downstream the plant growth and development process (hormonal regulation) and also affect the changes in the molecular and biochemical phenomenon (RAMAKRISHNA and RAVISHANKAR, 2011; SHESHADRI et al, 2016). Moreover, the researcher proved that these changes are governed by gene (s) or combination of cis-regulatory elements (TFs) especially those associated with transcriptional regulation of associated genes (SHESHADRI et al, 2016; JOSHI et al, 2016). These elements bind to their specific recognition sites of stress responsive genes and affects the primary and secondary metabolites networks in the plants systems under abiotic conditions (DURAISAMY et al, 2016; CARETTO et al, 2015; OSAKABE et al, 2014; SCHULTER et al, 2013).

Artemisinin (sesquiterpenes) is biosynthesized and accumulate in the leaf of $A$. annua L. plants and strictly controlled by spatial and temporal manner and affected by several abiotic factors responsive elements led the low artemisinin content $(\sim 1.0 \%)$ is reported in A. annua $\mathrm{L}$. plants wordwide (SHEN et al, 2019; ALAM et al, 2016; ALAM and ABDIN, 2012; ALAM et al, 2010; MA et al, 2009).

These spatiotemporal elements play an important role in metabolic pathways to up-regulate the metabolic fluxes by interacting the signature sequences i.e. regulatory region in plant genome of the targeted gene (s) and modulate the transcription levels (BUSSEMAKER et al, 2001). Despite the remarkable progresses have been achieved in artemisinin production either though understand the role of cis-elements or genetic engineering approaches in plants and microbes (ABDIN and ALAM, 2015; PADDON et al, 2013), A. annua is the only valuable source for artemisinin (PEPLOW, 2016; ABDIN and ALAM, 2015). However, the transcriptional regulation of artemisinin pathway in A. annua is not yet well established. More recently, some transcription factors (AabZIP9, AabZIP1, AaABF3, AabZIP1) are characterized and targeted as transcriptional regulators those playing a significant role in Artemisia annua L. plant development, metabolism under abiotic stress conditions (CHEN et al, 2016; TANG et al, 2012; OSTERLUND et al, 2000; ANG et al, 1998).

Hence, we, emphasized that the cis-elements is the key factors to play an important role in artemisinin biosynthesis under the stress conditions. In this article, we predicted the cis-elements from Artemisia annua L. ESTs retrieve from NCBI $\mathrm{db}$ to assess their biological role associated with particular gene (s) by comparing the genome of Arabidopsis thaliana (TAIR data base) under salt condition. The functional analysis; Gene Ontology (GO) enrichment analysis of the predicted unigenes were also assessed their role or resemble function in term of cellular biological and molecular.

\section{Materials and Methods}

In this study, 127 ESTs of $A$. апnиа L. were retrieved from NCBI under salt stress. In order to analysis the similarity-based clustering of the ESTs for its enhance effectiveness were screened to abolish the vector sequences caused inappropriate clustering through Vec screen on line tool from NCBI (https://www.ncbi.nlm.nih.gov/tools/vecscreen/). The trimmed ESTs sequences were assembled into clusters constructed on the basis of sequences resemblance to obtained the constant clusters using CAP3 online program (http://doua.prabi.fr/software/cap3), with default (HUANG and MADAN, 1999). Each cluster were separately the with overlap identity as cut off range showed the minimum sum of nucleotides. Ungrouped sequences, with low identity recorded as singletons may be a formed of genes or may be an outcome of contamination, were not counted for abiotic stress-responding elements and functional annotations.

\section{Identification of abiotic stress-responding elements and its functional annotation}

PlantCare, Plant PAN were used for transcriptions start site (TSS) and the promoter region for all of these genes were obtained. The cis-regulatory elements of abiotic signaling related gene were predicted from Plant CARE (LESCOT et al, 2002), and PlantPAN3.0 (CHOW et al, 2019) to find out an occurrence of motifs at the promoter regions. The presence of abiotic stress responsive factors annotation at the promoter region of a gene was considered as a marker for determining the putative abiotic stress responsive role for that gene. This consideration was based on the ration that a large portion of the gene expression control takes place at the transcriptional level. After identification of abiotic stress-responsive genes, functional analysis of the assembled contigs was performed, Gene Ontology (GO) enrichment analysis for stress-responsive genes were carried out to determine their role in biological processes, molecular function, and cellular component using GO vocabularies by online Gene Ontology tool (goProfiler), Blast2go and STRING 10.0 (http://string-db.org).

\section{Results}

\section{Contigs prediction: EST assembly}

Identification of putative abiotic stress responsive genes of A. аппиа L. were predicted by analyses of ESTs, under salinity. A total of 127 ESTs of A. аппиа L. were obtained from NCBI GenBank. Out of 127 EST sequences, 2 sequences were trimmed and rest of 125 sequences were assembled and predicted 11 contigs through the CAP3 program (http://doua.prabi.fr/software/cap3). Assembled ESTs interpretation for solitary $8.66 \%$ of the size of total number of ESTs. Less abundant or deprived ESTs were not assembled and known as singletons (26).

\section{Identification of TFs}

In addition, cis-regulatory motifs were predicted by using the PlantCARE and PlantPAN 3.0 data base from 11 assembled contigs of $A$. annua L. plants. These 11 assembled contigs were predicted, cis-regulatory motifs involved in cold, light, salt, abscisic acid etc. responses. Of 127 
collected unigenes under salinity condition, at least more than one cis-regulatory motifs were found at the promoter region of 11 contigs to 29 signals elements. Since many of the genes had unknown protein annotation, the accession number and description were obtained from PlantPAN 3.0, TAIR, UniProtKB for cis-regulatory motifs (Table 1).

Table 1. Prediction of cis-motif from ESTs-contigs Artemisia annua L. under salinity

\begin{tabular}{|c|c|c|c|}
\hline Signals & ID & Functions & Sequence \\
\hline$\overline{\text { ABRE }}$ & $\begin{array}{l}\text { Contigs1 } \\
\text { Contigs3 } \\
\text { Contigs9 } \\
\text { Contigs11 }\end{array}$ & Abscisic acid responsive element-binding factor 1 & ACGTG \\
\hline CAAT-box & $\begin{array}{l}\text { Contigs1 } \\
\text { Contigs2 } \\
\text { Contigs3 } \\
\text { Contigs4 } \\
\text { Contigs5 } \\
\text { Contigs6 } \\
\text { Contigs7 } \\
\text { Contigs8 } \\
\text { Contigs9 } \\
\text { Contigs10 } \\
\text { Contigs11 } \\
\end{array}$ & $\begin{array}{l}\text { Encodes a homeodomain leucine zipper class I (HD-Zip I) meristem } \\
\text { identity regulation }\end{array}$ & CCAAT \\
\hline DRE core & $\begin{array}{l}\text { Contigs1 } \\
\text { Contigs5 } \\
\text { Contigs11 }\end{array}$ & Cold tolerance in maize & GCCGAC \\
\hline G-Box & $\begin{array}{l}\text { Contigs1 } \\
\text { Contigs3 } \\
\text { Contigs11 }\end{array}$ & Phytochrome interacting factor 3-light responsive & CACGTT \\
\hline GATA-motif & $\begin{array}{l}\text { Contigs } 1 \\
\text { Contigs4 } \\
\text { Contigs7 } \\
\text { Contigs 10 }\end{array}$ & GATA type zinc finger transcription factor family protein-light & GATAGGA \\
\hline MYB & $\begin{array}{l}\text { Contigs1 } \\
\text { Contigs2 } \\
\text { Contigs3 } \\
\text { Contigs4 } \\
\text { Contigs5 } \\
\text { Contigs8 } \\
\text { Contigs9 } \\
\text { Contigs11 }\end{array}$ & Homeodomain-like superfamily protein-response to salt stress & TAACTG \\
\hline P-box & $\frac{\text { Contigs1 }}{\text { Contigs5 }}$ & Gibberellin-responsive element-rice & CCTTTTG \\
\hline STRE & $\begin{array}{l}\text { Contigs1 } \\
\text { Contigs2 } \\
\text { Contigs4 } \\
\text { Contigs5 } \\
\text { Contigs6 } \\
\text { Contigs7 } \\
\text { Contigs8 } \\
\text { Contigs11 }\end{array}$ & Salt tolerance zinc finger & AGGGG \\
\hline Sp1 & $\begin{array}{l}\text { Contigs1 } \\
\text { Contigs } 8\end{array}$ & Phosphotyrosine protein phosphatases superfamily protein-light & GGGCGG \\
\hline TCA-element & $\begin{array}{l}\text { Contigs1 } \\
\text { Contigs2 } \\
\text { Contigs4 } \\
\text { Contigs5 } \\
\text { Contigs11 }\end{array}$ & $\begin{array}{l}\text { Abscisic acid responsive element-binding factor 1, is-acting element } \\
\text { involved in salicylic acid responsiveness }\end{array}$ & CCATCTTTTT \\
\hline CGTCA-motif & $\begin{array}{l}\text { Contigs2 } \\
\text { Contigs3 } \\
\text { Contigs6 } \\
\end{array}$ & $\begin{array}{l}\text { Cis-acting regulatory element involved in the MeJA- } \\
\text { responsiveness, Hordeum vulgare }\end{array}$ & CGTCA \\
\hline MYC & $\begin{array}{l}\text { Contigs2 } \\
\text { Contigs3 } \\
\text { Contigs4 } \\
\text { Contigs5 } \\
\text { Contigs11 }\end{array}$ & Jasmonate-zim-domain protein 1 & CAATTG \\
\hline TGACG-motif & $\begin{array}{l}\text { Contigs2 } \\
\text { Contigs3 } \\
\text { Contigs6 } \\
\end{array}$ & $\begin{array}{l}\text { Cis-acting regulatory element involved in the MeJA-responsiveness, } \\
\text { basic leucine zipper transcription factor involved in the activation of } \\
\text { SA-responsive genes }\end{array}$ & TGACG \\
\hline as-1 & $\begin{array}{l}\text { Contigs2 } \\
\text { Contigs3 } \\
\text { Contigs6 } \\
\end{array}$ & salt stress & TGACG \\
\hline$\overline{\text { ARE }}$ & $\begin{array}{l}\text { Contigs3 } \\
\text { Contigs4 } \\
\text { Contigs8 } \\
\end{array}$ & Response to salt stress, response to heat & AAACCA \\
\hline LTR & Contigs3 & $\begin{array}{l}\text { Cis-acting element involved in low-temperature responsiveness- } \\
\text { Hordeum vulgare }\end{array}$ & CCGAAA \\
\hline MBS & $\begin{array}{l}\text { Contigs2 } \\
\text { Contigs3 } \\
\text { Contigs } 8 \\
\end{array}$ & $\begin{array}{l}\text { MYB binding site involved in drought-inducibility-Abscisic acid- } \\
\text { activated signaling pathway }\end{array}$ & CAACTG \\
\hline TCT-motif & Contigs4 & Part of a light responsive element-Arabidopsis & TCTTAC \\
\hline AP-1 & Contigs5 & Gibberellic acid biosynthetic pathway-light & TGAGTTAG \\
\hline GARE-motif & Contigs5 & Gibberellin-responsive element-Bracica oleracea & TCTGTTG \\
\hline ERE & Contigs7 & Ethylene responsive binding fator & ATTTTAAA \\
\hline GT1-motif & Contigs7 & Light responsive element-arabidosis thaliana & GGTTAA \\
\hline TGA-element & Contigs8 & Auxin-responsive element,gibberellin catabolic process-heat & AACGAC \\
\hline W box & Contigs8 & Homeodomain-like superfamily protein-salt stress & TTGACC \\
\hline
\end{tabular}


Role of ESTs in Abiotic signaling in A. annua L.

\begin{tabular}{|c|c|c|c|}
\hline GC-motif & Contigs9 & $\begin{array}{l}\text { Enhancer-like element involved in anoxic specific inducibility-abscisic } \\
\text { acid-activated signaling pathway }\end{array}$ & CCCCCG \\
\hline box $\mathbf{S}$ & Contigs9 & Cold tolerance -Homeodomain-like superfamily protein & GCCACT \\
\hline CAT-box & Contigs11 & Jasmonic acid mediated signaling pathway-cold & GCCACT \\
\hline CCAAT-box & $\begin{array}{l}\text { Contigs } 3 \\
\text { Contigs } 11\end{array}$ & Member of Cation-chloride co-transporter family-salt stress & CAACGG \\
\hline WRE3 & $\begin{array}{l}\text { Contigs } 1 \\
\text { Contigs } 9\end{array}$ & wound-response element reported in Pisum sativum & CCACCT \\
\hline BOX 4 & $\begin{array}{l}\text { Contigs4 } \\
\text { Contigs7 } \\
\text { Contigs } 10\end{array}$ & $\begin{array}{l}\text { Part of a conserved DNA module involved in light responsiveness in } \\
\text { Petroselinum crispum }\end{array}$ & ATTAAT \\
\hline TC-rich repeats & Contigs7 & $\begin{array}{l}\text { Cis-acting element involved in defense and stress responsiveness in } \\
\text { Nicotiana tabacum }\end{array}$ & GTTTTCTTAC \\
\hline
\end{tabular}

\section{Functional annotation of EST-contigs}

Moreover, 11 contigs were functionally annotated and compared with the NCBI nr database by using the BLAST2GO OMICS box program. The BLAST results revealed above $50 \%$ sequences were conserved to Arabidopsis thaliana followed by Lemna gibba and Nicotiana tabacum as compared to others (Fig. 1-2). Further, these ESTs-contigs were carried out to gene ontology (GO) for their functional role. The available GO terms; only 4 ESTcontigs. $27 \mathrm{GO}$ terms repossessed, representing a usual of $2 \mathrm{GO}$ terms/contig (minimum) and one contig for $18 \mathrm{GO}$ terms (maximum) were recorded for this study (Fig. 3).

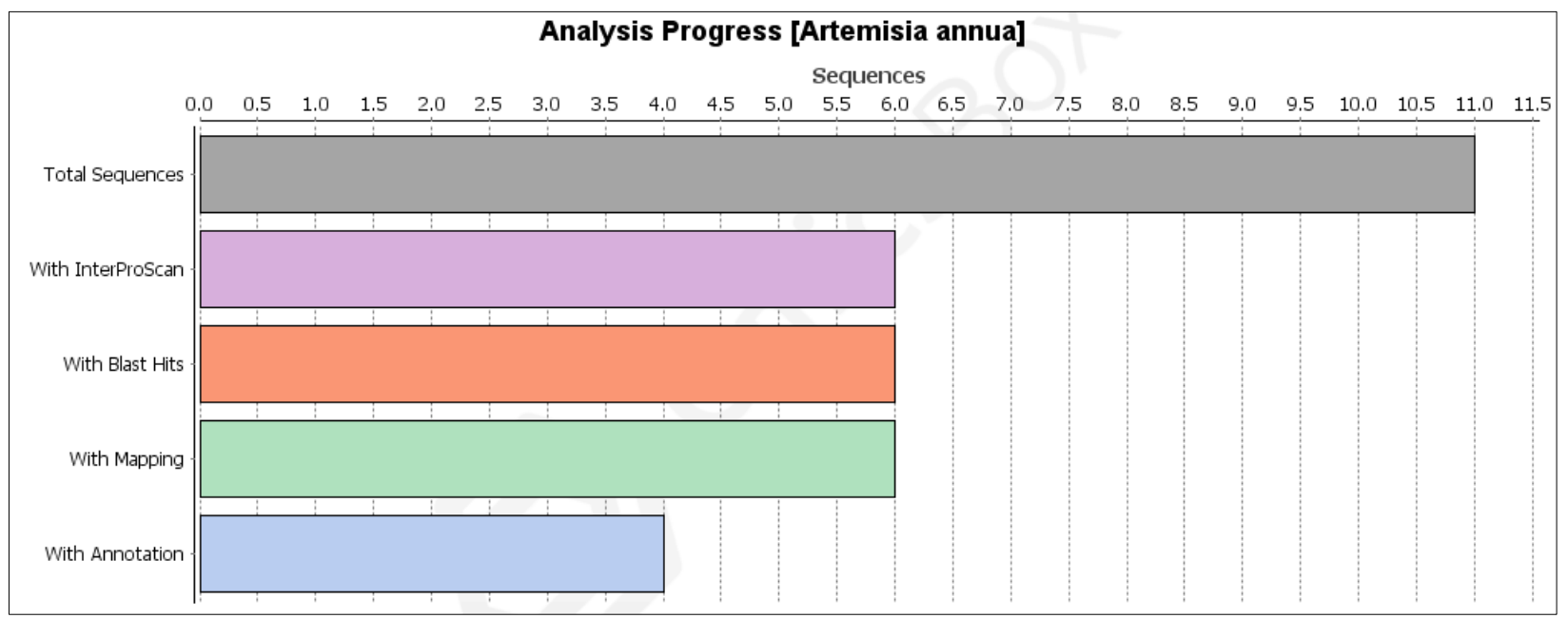

Figure 1. Total number of sequences (contigs) analysed through BLAST, InterproScan, mapping and annotation by OMICS BOX having blast2go program.

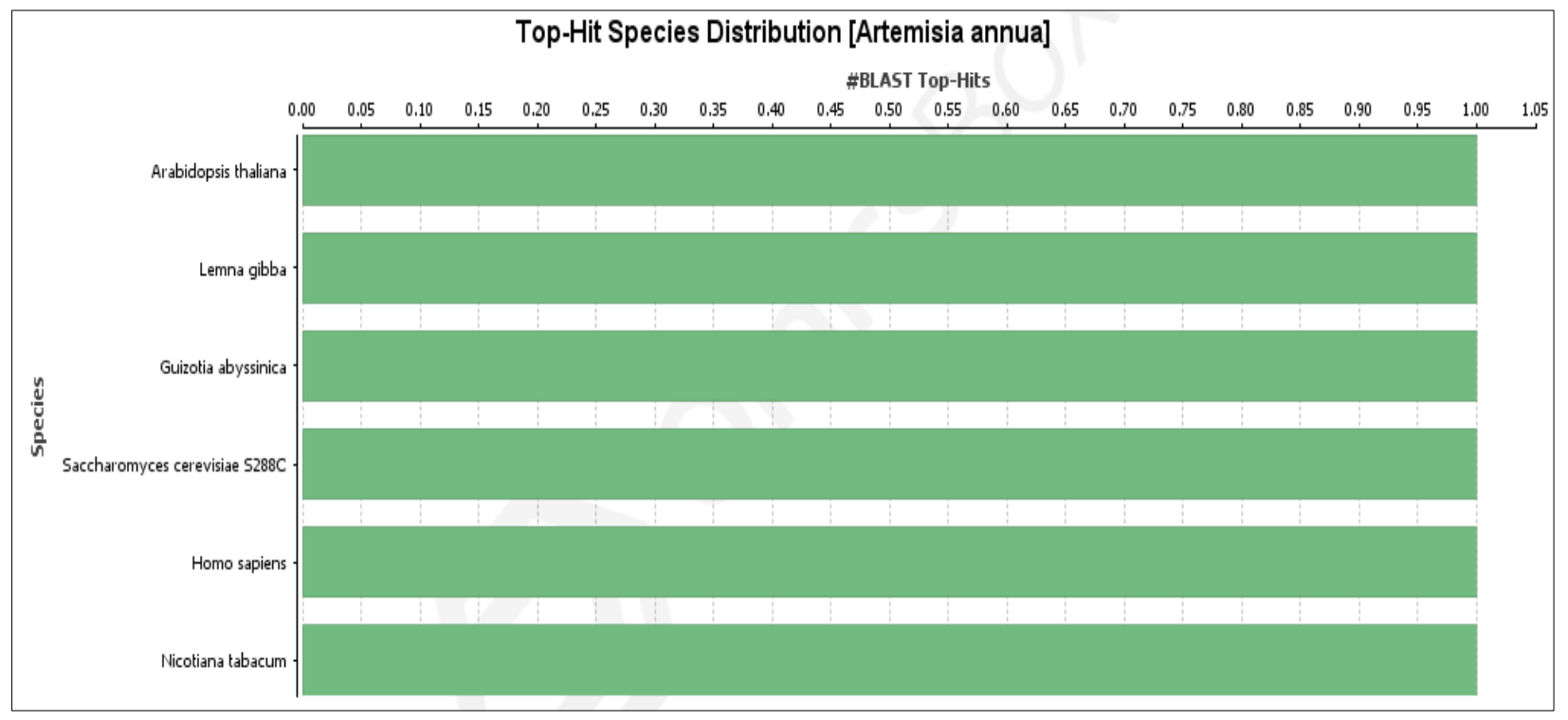

Figure 2. Top hit species distribution of assembled contigs from A. апnиa L. plants. 


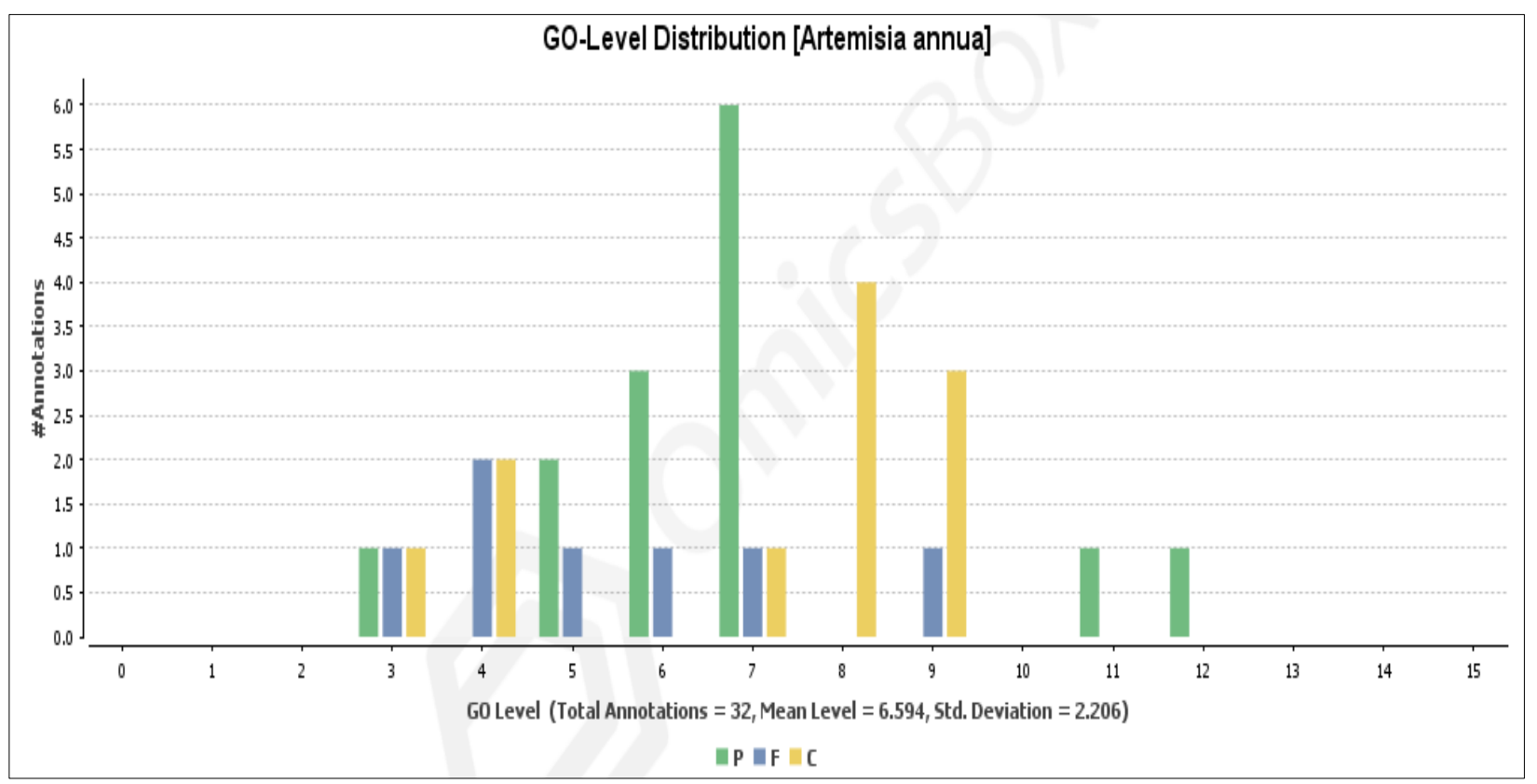

Figure 3. GO-level distribution graph produced by BLAST2GO for ESTs-contigs sequences of Artemisia annua L. $\mathrm{P}$, biological process; $\mathrm{F}$, molecular function; and $\mathrm{C}$, cellular component.

Further, functional characterized of 11 ESTs-contigs were for further analyzed for biological process, cellular component and molecular function at level three (Fig. 4a, $\mathrm{b}, \mathrm{c})$. GO analysis in which whole genome annotation assumed as reference (Arabidopsis thaliana), demonstrated that 28 identified genes out of 31 , were significantly enriched as abiotic signaling responsive genes at $\mathrm{p}$-value of 0.05. According to Gene Ontology-Biological Process (GOBP) analysis, 31 enriched genes had hits with GOBP belongs to abiotic stress and diterpenoid biosynthesis signaling by using gProfilar program. The majority of genes were enriched as response to stimulus (cluster frequency of $29 \%$ ) and $(50 \%)$ response to abiotic stress signaling. Furthermore, few of gene enriched as a specific GOBP response to abscisic acid, jasmonic acid, auxins and gibberellic acid for response under salinity (Table S1). GO Slim-plant analysis enriched genes into response to stress with p-value of $1.16 \mathrm{E}-07$ and $24 / 28$ number of gene (cluster frequency of $85.71 \%$ ) (Fig. $4 a, b$ and c).

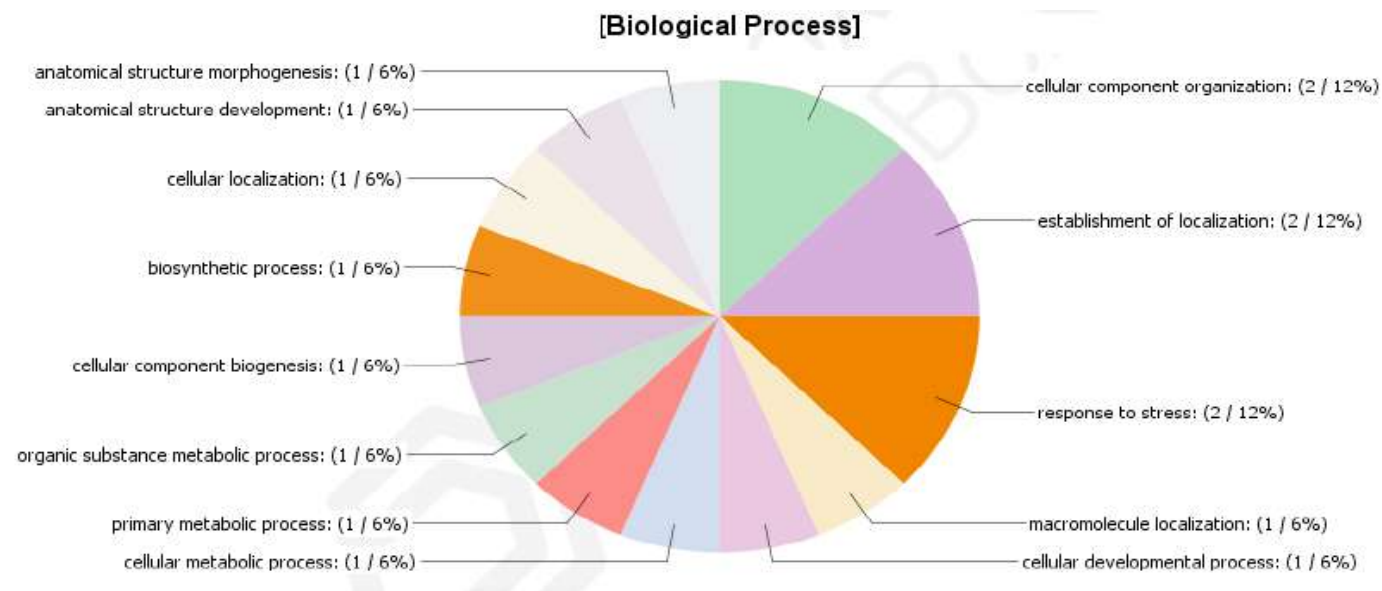

Fig. 4a 


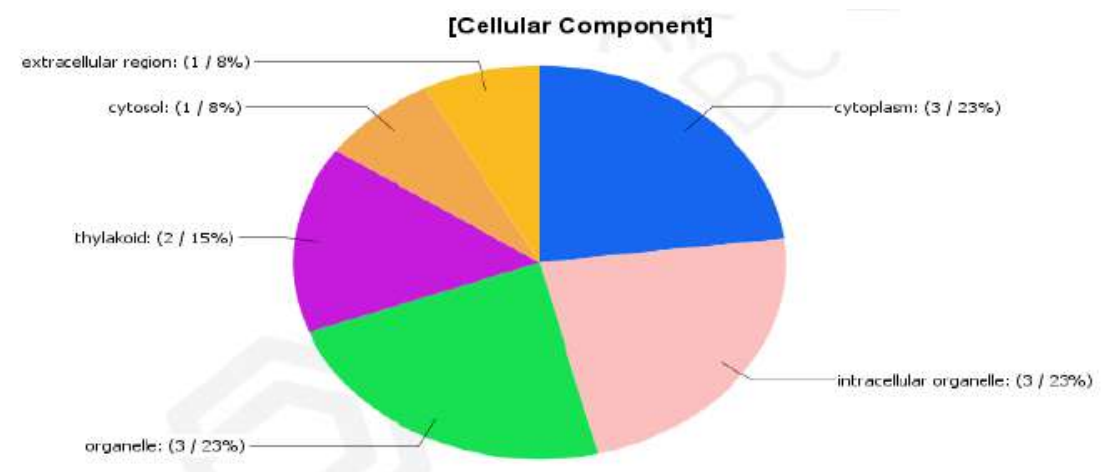

Fig. 4b

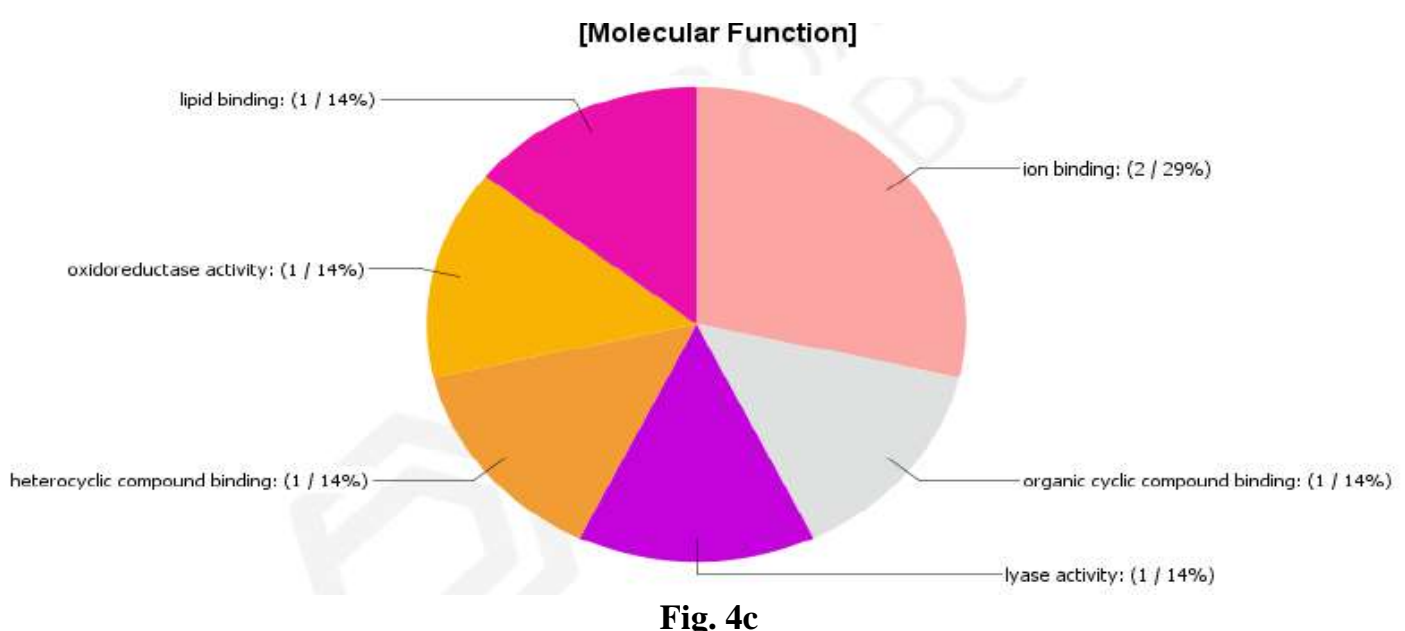

Figure 4. Gene ontology classification of EST-contig sequences of Artemisia аппиа L. (a): Distribution of GO terms in the biological process category. (b): Distribution of GO terms of in the cellular process category. (c): Distribution of GO terms of in the molecular function category.

Other genes were involved either in biotic process like wound healing, signal transduction, cell communications under salt stress (Table S2). The results of GO Slim-plant analysis putative stress responsive genes determined by cis-regulatory element detection method is further confirmed through the STRING 10.0 indicated the presence of specific domain known for stress response (Fig. 5). The results of STRING 10.0 based on PFAM Protein Domains PF13188, PF08446,PF,00360, PF08448 and PF01590) and INTERPRO Protein Domains (IPR0035965, IPR029016, IPR018467, IPR016132 and IPR013767 and PF00582) and Features databases indicated 5 domains belongs to abiotic universal stress protein family (Pathway ath04712, ath04075 and ath00904) were significantly enriched for proteins AT2G17290.1 and AT1G01560.2 (Fig. 5 Table S2). All identified putative abiotic stress responsive genes indicated correlation above 0.4 and mutual connection of at least 0.7 . The results of co-expression analysis were confirmed using produced Protein-Protein Interaction (PPI) network by gene investigators (Fig. 5).

\section{Discussion}

The substantial progresses in artemisinin biosynthesis are achieved in heterologous hosts by using the different cutting-edge technology (ABDIN and ALAM, 2015;
PADDON et al, 2013; ALAM and ABDIN, 2011). At this stage, A. annua is still the only reliable and effective resource for artemisinin production. It is because of artemisinin and its competitive pathways which played an important role to transfer the carbon fluxes towards artemisinin biosynthesis (PEPLOW, 2016; ABDIN and ALAM, 2015) in A. annua L. plants. Though, the transcriptional factors and its regulation controlled the artemisinin biosynthesis pathway in $A$. апnиa is not yet well recognized. But some factors e.g bZIP transcription, abscisic acid (ABA) response AabZIP1, and AaABF3 and WRKKY were studied by some investigators and play important role for plant growth development processes, metabolism, with under un favorable conditions i.e. abiotic or stress (ZHONG et al, 2018; CHEN et al, 2016; ZHANG et al, 2015; TANG et al, 2012; OSTERLUND et al, 2000; ANG et al. 1998) led increase artemisinin biosynthesis if over expressed in A. annua L. plants. In this study almost all identified factors (ABF1, APX CCC1, CPK6, JAZ1, MYC2 and JAZ5) with leading under salt stress when compared to Arabidopsis thaliana genome used as a reference (Table 1) while AT1G10588.1 (auxin response factor family) and AT1G59750. (Gibberellin-regulated protein family) did not show expression potential under salt stress in A. annua L. plants. (Fig. 5, THAKUR, 2010; MIURA and TADA 2014). 


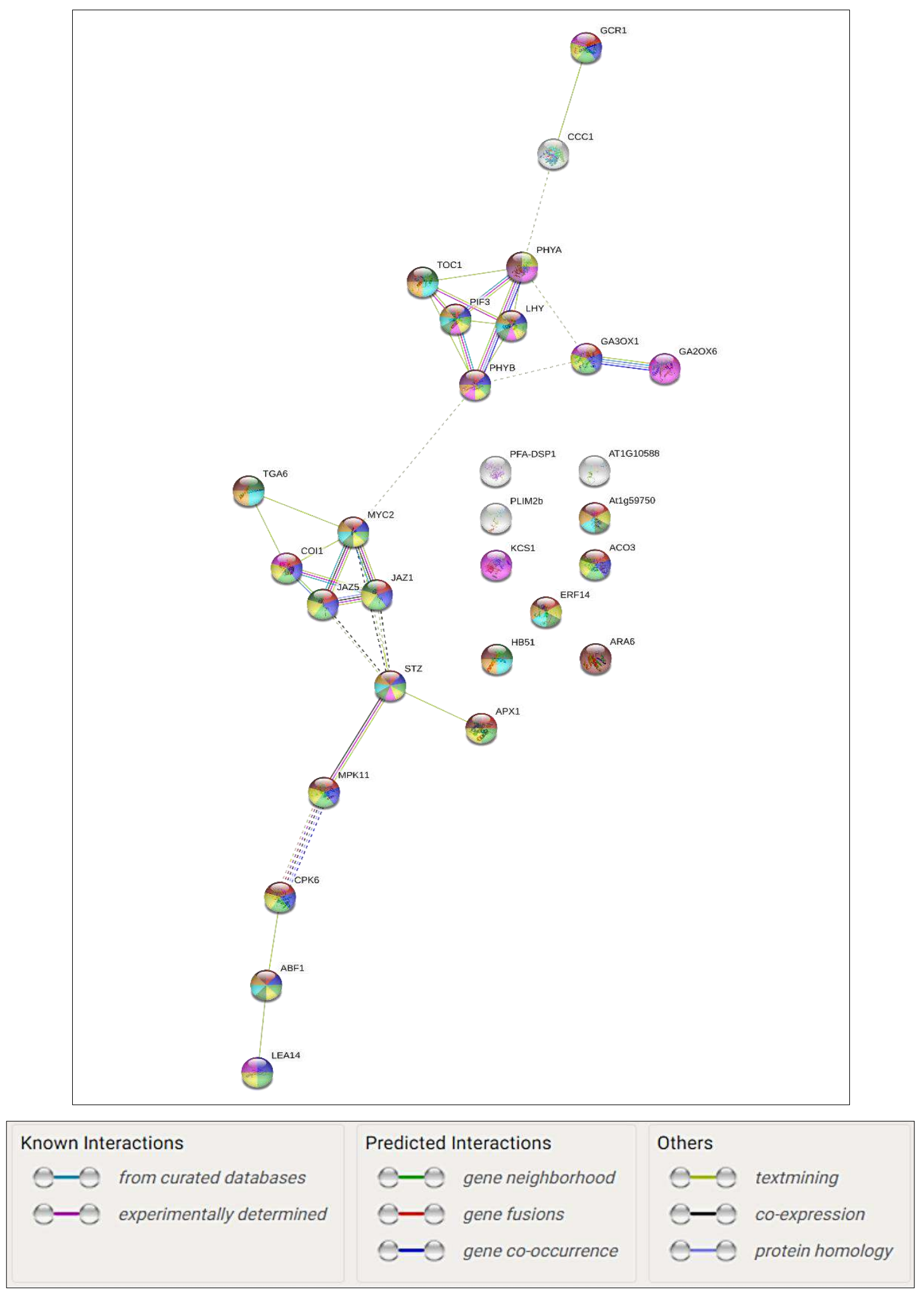

Figure 5. The interaction partners of the significant proteins network i.e. association of gene networking from STRING10.0. The inferences of different colorful outlines between the proteins are presented below the network map.

Most of identified genes from 11 unigenes of A. аппи $\mathrm{L}$. obtained through ESTs assembly corresponding proteins showed interaction between themselves. Different correlation calculations have been used for categorizing gene expression data. Co-expression analysis, indeed, reveals response of genes to a particular stress or more stresses with some similar consequences. Furthermore, in order to confirm co-expressed genes, their co-regulation might be evaluated for having similar cis-regulatory elements by String 10.0 (SHARMA, 2015; SHINOZALI et al, 2000). 
Therefore, to check out assumed functionally related genes with same co-regulation pattern, comparing the results with A. thaliana genome data could be useful.

$\mathrm{GO}$ analysis enriched the major of identified genes $(85.71 \% \%)$ as responsive genes to stimuli and GO Slimplant analysis enriched all genes into "response to stress". Salinity and ABA treatment mostly similar regulatory elements and signal transduction pathways with abscisic acid dependent pathways (SHINOZAKI et al, 2000). Major part of the genes showed potential of expression under salt, drought, Jasmonate and ABA treatment as well as similar co-expression pattern with correlation and mutual connection of more than 0.40 (Table S1).

According to the obtained results, all predicted genes for 11 assembled contigs represented acceptable correlation based on Pearson's correlation coefficient (Fig. 5). The co-expression analysis results demonstrated the accuracy of the cis-regulatory elements detection to confirm the functional relationship of proteins encoded with the identified genes in response to particular stress conditions. STRING 10.0 provides user friendly interface by which could easily study proteins of interest based on physical and functional association from various known predicted interactions scattered over databases (SZKLARCZYK et al, 2014). As shown in (Table S2), more than $63 \%$ of the identified genes from goProfiler showed interaction with each other in protein level. These data illustrated accordance of coexpression results with their functional property.

PPI network also indicated that proteins encoded by identified genes had interactions with each other in co-expression prediction (Fig. 5). In this study of A. annua L. unigene, these unigenes play important role in different abiotic responsive pathways consequence of salt, drought, and temperature stress; plant signaling hormone pathways (ABA-dependent pathway and jasmonate pathway) and diterpenoid pathway in which the central role of ABF1, APX CCC1, CPK6, JAZ1, MYC2 and JAZ5 transcription factors including well characterized (Table 1). The observed transcription factors have also been characterized in many plants and play an important role in cellular activities eg. transcriptional activators, RNA polymerase activation and initiation of transcription and DNA binding transcriptional factor activity under different environmental stress (KVINT et al, 2003; KERK et al, 2003; Fig. 4a-c, Fig. 5, Table S2). On the basis of our analyses we, it has been suggested that the A. аппиа L. plants ESTs based factors associated genes regulates the hormonal regulation activity and elucidate the biosynthetic pathway. Therefore, it is now confirmed that the identified factors predicted from assembled unigenes/contigs using known cis-regulatory elements play an important role in plant yields and metabolites production (XIONG, 2005; RIANO-PACHON, 2007; ZHANG et al, 2005; BRIVANLOU and DARNELL, 2002). In other study, Sharma et al. (2015) in silico demonstrated that those genes that are co-expressed under stress share similar cis-regulatory elements are co-regulated with the same regulatory system under abiotic stress conditions. The protective role of these elements has been indicated in response to salt, drought and osmotic stress induced by salt treatments (YOSHIDA et al, 2014; NAKASHIMA et al, 2013 FUJITA et al, 2011).

\section{Conclusions}

Stresses influenced the signaling process that affect the common regulatory system and cross-talk in term of molecular changes. These molecular changes in regulatory network of plants affect the biosynthesis of metabolites and ultimately lead to stunt the plant growth. In this study, we made the relationship of predicted unigenes/contigs by ESTs assembly involved in the processes of plant signaling and diterpenoids pathways observed by GO analyses. The assembled unigenes obtained from Artemisia annua L. plants ESTs might play important role in plant growth development and artemisinin production. Since co-expression and mutual connection of genes could be a reliable indicator of their involvement in certain environmental factors, these identified unigenes based transcription factor (specially ABF1 JAZ1 and JAZ5 MYC1 CPK6) if overexpressed in A. annua L. it may lead to enhanced the production of artemisinin and plant development.

\section{Conflict of Interest}

The authors have no conflict of interest to declare.

\section{Acknowledgments/Funding}

This project was supported by the Deanship of Scientific Research at Prince Sattam bin Abdulaziz University under the research project \#2020/01/16362

\section{References}

1. ABDIN MZ, ALAM P (2015). Genetic engineering of artemisinin biosynthesis: prospects to improve its production. Acta Physiol Plant 37:33, doi.org/10.1007/s11738015-1771-5.

2. ALAM P, ABDIN MZ (2011). Over-expression of HMG-CoA reductase and amorpha-4,11-diene synthase genes in Artemisia annua L. and its influence on artemisinin content. Plant Cell Rep 10:1919-1928.

3. ALAM P, KIRAN U, AHMAD MM, KAMALUDDIN KHAN MA, JHANWAR S, ABDIN MZ (2010). Isolation, characterization and structural features of amorpha - 4,11-diene synthase ( $\mathrm{ADS}_{3963)}$ from Artemisia annua L. Bioinformation 4:421-429.

4. ALAM, P, KAMALUDDIN, SHARAF-ELDIN, MA et al. (2016). The effect of over-expression of rate limiting enzymes on the yield of artemisinin in Artemisia annua. Rend. Fis. Acc. Lincei 27:311-319.

5. ANG LH, CHATTOPADHYAY S, WEI N, OYAMA T, OKADA K, BATSCHAUER A et al. (1998) Molecular interaction between COP1 and HY5 defines a regulatory switch for light control of Arabidopsis development. Mol. Cell 1:213-222.

6. BRIVANLOU AH, DARNELL JE (2002). Signal transduction and the control of gene expression. Science. 295: 813-818.

7. BUSSEMAKER HJ, LI H, SIGGIA ED (2001). Regulatory element detection using correlation with expression. Nat Genet 27: 167-171.

8. CARETTO S, LINSALATA V, COLELLA G, MiTA G, LATTANZIO V (2015). Carbon Fluxes between Primary Metabolism and Phenolic Pathway in Plant Tissues under Stress. Int. J. Mol. Sci. 16: 26378-26394. 
9. CHEN XB, YAO QF, GAO XH, JIANG CF, HARBERD NP, FU XD (2016). Shoot-to-root mobile transcription factor HY5 coordinates plant carbon and nitrogen acquisition. Curr. Biol. 26:640-646.

10. CHOW CN, LEE TY, HUNG YC, LI GZ, TSENG KC, LIU YH, KUO PL, ZHENG HQ, CHANG WC (2019). PlantPAN3.0: a new and updated resource for reconstructing transcriptional regulatory networks from ChIP-seq experiments in plants. Nucleic Acids Res 47(D1):D1155-D1163.

11. DURAISAMY GS, MISHRA AK, KOCABEK T, MATOUŠEK J (2016). Identification and characterization of promoters and cis-regulatory elements of genes involved in secondary metabolites production in hop (Humulus lupulus. L). Comput. Biol. Chem 64:346-352.

12. FUJITA Y, FUJITA M, SHINOZAKI K, YAMAGUCHISHINOZAKI K (2011). ABA-mediated transcriptional regulation in response to osmotic stress in plants. Journal of plant research 124: 509-525.

13. HAGGAG WH, ABOUZIENA HF, ABD-EL-KREEM F, EL HABBASHA S (2015). Agriculture biotechnology for management of multiple biotic and abiotic environmental stress in crops. J. Chem. Pharm. Res 7, 882-889.

14. HUANG X, MADAN A (1999). CAP3: A DNA sequence assembly program. Genome Res. 9:868-77.

15. JENKS MA, HASEGAWA PM (2005). Plant Abiotic Stress. (Blackwell, Oxford, 2005).

16. JOSHI R, WANI SH, SINGH B, BOHRA A, DAR ZA, LONE AA, PAREEK A, SINGLA-PAREEK SL (2016). Transcription Factors and Plants Response to Drought Stress: Current Understanding and Future Directions. Front Plant Sci 7:1029. doi: 10.3389/fpls.2016.01029

17. KERK D, BULGRIEN J, SMITH DW, GRIBSKOV M (2003). Arabidopsis proteins containing similarity to the universal stress protein domain of bacteria. Plant Physiol 131: 1209-1219.

18. KVINT K, NACHIN L, DIEZ A, NYSTROM (2003). The bacterial universal stress protein: function and regulation. Current opinion in microbiology 6: 140-145.

19. LESCOT M, DÉHAIS P, THIJS G, MARCHAL K, MOREAU Y, VAN DE PEER Y, ROUZÉ P, ROMBAUTS S (2002). PlantCARE, a database of plant cis-acting regulatory elements and a portal to tools for in silico analysis of promoter sequences. Nucleic Acids Res 30:325-7.

20. MA D, PU G, LEI C, MA L, WANG H, GUO Y, CHEN J, DU Z, LI G, YE H, LIU B (2009b). Isolation and characterization of AaWRKY1, an Artemisia annua transcription factor that regulates the amorpha- 4,11-diene synthase gene, a key gene of artemisinin biosynthesis. Plant Cell Physiol. 50:2146-2161.

21. MIURA K, TADA Y (2014). Regulation of water, salinity, and cold stress responses by salicylic acid. Frontiers in plant science. 5: 4. doi.org/10.3389/fpls.2014.00004

22. NAKASHIMA K, YAMAGUCHI-SHINOZAKI K (2013) ABA signaling in stress-response and seed development. Plant Cell Rep 32: 959-970.

23. OSAKABE Y, OSAKABE K, SHINOZAKI K AND TRAN L-SP (2014). Response of plants to water stress. Front. Plant Sci 5:86. doi: 10.3389/fpls.2014.00086

24. OSTERLUND MT, HARDTKE CS, WEI N, DENG XW (2000). Targeted destabilization of HY5 during light-regulated development of Arabidopsis. Nature 405:462-466.

25. PADDON CJ, WESTFALL PJ, PITERA DJ, BENJAMIN K, FISHER K, MCPHEE D et al (2013). High-level semi-synthetic production of the potent antimalarial artemisinin. Nature 496:528-532.
26. PELEG Z, APSE MP, BLUMWALD E (2011). Engineering salinity and water-stress tolerance in crop plants: getting closer to the field. Adv. Bot. Res 57, 405-443.

27. PEPLOW M (2016). Synthetic biology's first malaria drug meets market resistance. Nature 530:389-390.

28. RAMAKRISHNA A, RAVISHANKAR GA (2011). Influence of abiotic stress signals on secondary metabolites in plants. Plant Signal Behav. 6, 1720-1731.

29. RIANO-PACHON DM (2007). PlnTFDB: an integrative plant transcription factor database. BMC bioinformatics 8 : 42. doi.org/10.1186/1471-2105-8-42

30. SCHLÜTER U, COLMSEE C, SCHOLZ U, BRÄUTIGAM A, WEBER AP, ZELLERHOFF N, BUCHER M, FAHNENSTICH H, SONNEWALD U (2013). Adaptation of maize source leaf metabolism to stress related disturbances in carbon, nitrogen and phosphorus balance. BMC Genomics 14:442. doi.org/10.1186/ 1471-2164-14-442

31. SHARMA A (2015). In silico identification of regulatory motifs in co-expressed genes under osmotic stress representing their co-regulation. Plant Gene. 1: 29-34.

32. SHEN Q, HUANG H, ZHAO Y, XIE L, HE Q, ZHONG Y, WANG Y, WANG Y, TANG K (2019). The Transcription Factor Aabzip9 Positively Regulates the Biosynthesis of Artemisinin in Artemisia annua. Front Plant Sci. 10:1294. doi:10.3389/fpls.2019.01294

33. SHESHADRI SA, NISHANTH MJ, SIMON B (2016). Stress-Mediated cis-Element Transcription Factor Interactions Interconnecting Primary and Specialized Metabolism in planta. Front Plant Sci. 7:1725.

34. SHINOZAKI K, YAMAGUCHI-SHINOZAKI K (2000). Molecular responses to dehydration and low temperature: differences and cross-talk between two stress signaling pathways. Current opinion in plant biology 3: 217-223.

35. SZKLARCZYK D, FRANCESCHINI A, WYDER S, FORSLUND K, HELLER D, HUERTA-CEPAS J et al. (2014). STRING v10: protein-protein interaction networks, integrated over the tree of life. Nucleic acids res 43: 447-452.

36. TANG N, ZHANG H, LI XH, XIAO JH, XIONG LZ (2012). Constitutive activation of transcription factor OsbZIP46 improves drought tolerance in rice. Plant Physiol 158:1755-1768.

37. THAKUR P (2010). Cold stress effects on reproductive development in grain crops: an overview. Environmental and Experimental Botany 67: 429-443.

38. XIONG Y (2005). Transcription factors in rice: a genomewide comparative analysis between monocots and eudicots. Plant mol. biol 59: 191-203.

39. YOSHIDA T, MOGAMI J, YAMAGUCHI-SHINOZAKI $\mathrm{K}$ (2014). ABA-dependent and ABA-independent signaling in response to osmotic stress in plants. Current opinion in plant biology 21: 133-139.

40. ZHANG F, FU X, LV Z, LU X, SHEN Q, ZHANG L et al. (2015). A basic leucine zipper transcription factor, AabZIP1, connects abscisic acid signaling with artemisinin biosynthesis in Artemisia annua. Mol. Plant 8:163-175.

41. ZHANG W, RUAN J, HO TH, YOU Y, YU T, QUATRANO RS (2005). Cis-regulatory element based targeted gene finding: genome-wide identification of abscisic acid-and abiotic stress-responsive genes in Arabidopsis thaliana. Bioinformatics 21: 3074-3081

42. ZHONG Y, LI L, HAO X, FU X, MA Y, XIE L et al. (2018). AaABF3, an abscisic acid-responsive transcription factor, positively regulates artemisinin biosynthesis in Artemisia annua. Front. Plant Sci 9:1777. doi: 10.3389/fpls.2018.01777 
Role of ESTs in Abiotic signaling in A. annua L.

TableS1: co-expression of 11 ESTs interactions in abiotic stress signallings

\begin{tabular}{|c|c|c|c|c|}
\hline \multicolumn{5}{|c|}{ Interactions } \\
\hline node1 & node2 & node1 accession & node2 accession & score \\
\hline ABF1 & CPK6 & AT1G49720.2 & AT2G17290.1 & 0.547 \\
\hline ABF1 & LEA14 & AT1G49720.2 & AT1G01470.1 & 0.518 \\
\hline APX1 & STZ & AT1G07890.8 & AT1G27730.1 & 0.58 \\
\hline $\mathrm{CCC} 1$ & GCR1 & AT1G30450.2 & AT1G48270.1 & 0.483 \\
\hline $\mathrm{CCC} 1$ & PHYA & AT1G30450.2 & AT1G09570.1 & 0.41 \\
\hline COI1 & JAZ1 & AT2G39940.1 & AT1G19180.1 & 0.998 \\
\hline COI1 & JAZ5 & AT2G39940.1 & AT1G17380.1 & 0.839 \\
\hline COI1 & MYC2 & AT2G39940.1 & AT1G32640.1 & 0.968 \\
\hline COI1 & TGA6 & AT2G39940.1 & AT3G12250.4 & 0.461 \\
\hline CPK6 & ABF1 & AT2G17290.1 & AT1G49720.2 & 0.547 \\
\hline CPK6 & MPK11 & AT2G17290.1 & AT1G01560.2 & 0.416 \\
\hline GA2OX6 & GA3OX1 & AT1G02400.1 & AT1G15550.1 & 0.928 \\
\hline GA3OX1 & GA2OX6 & AT1G15550.1 & AT1G02400.1 & 0.928 \\
\hline GA3OX1 & PHYA & AT1G15550.1 & AT1G09570.1 & 0.523 \\
\hline GA3OX1 & PHYB & AT1G15550.1 & AT2G18790.1 & 0.624 \\
\hline GCR1 & $\mathrm{CCC} 1$ & AT1G48270.1 & AT1G30450.2 & 0.483 \\
\hline JAZ1 & COI1 & AT1G19180.1 & AT2G39940.1 & 0.998 \\
\hline JAZ1 & JAZ5 & AT1G19180.1 & AT1G17380.1 & 0.935 \\
\hline JAZ1 & MYC2 & AT1G19180.1 & AT1G32640.1 & 0.997 \\
\hline JAZ1 & STZ & AT1G19180.1 & AT1G27730.1 & 0.791 \\
\hline JAZ5 & COI1 & AT1G17380.1 & AT2G39940.1 & 0.839 \\
\hline JAZ5 & JAZ1 & AT1G17380.1 & AT1G19180.1 & 0.935 \\
\hline JAZ5 & MYC2 & AT1G17380.1 & AT1G32640.1 & 0.971 \\
\hline JAZ5 & STZ & AT1G17380.1 & AT1G27730.1 & 0.41 \\
\hline LEA14 & ABF1 & AT1G01470.1 & AT1G49720.2 & 0.518 \\
\hline LHY & PHYA & AT1G01060.2 & AT1G09570.1 & 0.782 \\
\hline LHY & PHYB & AT1G01060.2 & AT2G18790.1 & 0.834 \\
\hline LHY & PIF3 & AT1G01060.2 & AT1G09530.2 & 0.665 \\
\hline LHY & TOC1 & AT1G01060.2 & AT5G61380.1 & 0.995 \\
\hline MPK11 & CPK6 & AT1G01560.2 & AT2G17290.1 & 0.416 \\
\hline MPK11 & STZ & AT1G01560.2 & AT1G27730.1 & 0.417 \\
\hline MYC2 & COI1 & AT1G32640.1 & AT2G39940.1 & 0.968 \\
\hline MYC2 & JAZ1 & AT1G32640.1 & AT1G19180.1 & 0.997 \\
\hline MYC2 & JAZ5 & AT1G32640.1 & AT1G17380.1 & 0.971 \\
\hline MYC2 & PHYB & AT1G32640.1 & AT2G18790.1 & 0.463 \\
\hline MYC2 & STZ & AT1G32640.1 & AT1G27730.1 & 0.635 \\
\hline MYC2 & TGA6 & AT1G32640.1 & AT3G12250.4 & 0.522 \\
\hline PHYA & $\mathrm{CCC} 1$ & AT1G09570.1 & AT1G30450.2 & 0.41 \\
\hline PHYA & GA3OX1 & AT1G09570.1 & AT1G15550.1 & 0.523 \\
\hline PHYA & LHY & AT1G09570.1 & AT1G01060.2 & 0.782 \\
\hline PHYA & PHYB & AT1G09570.1 & AT2G18790.1 & 0.781 \\
\hline PHYA & PIF3 & AT1G09570.1 & AT1G09530.2 & 0.998 \\
\hline PHYA & TOC1 & AT1G09570.1 & AT5G61380.1 & 0.795 \\
\hline PHYB & GA3OX1 & AT2G18790.1 & AT1G15550.1 & 0.624 \\
\hline PHYB & LHY & AT2G18790.1 & AT1G01060.2 & 0.834 \\
\hline PHYB & MYC2 & AT2G18790.1 & AT1G32640.1 & 0.463 \\
\hline PHYB & PHYA & AT2G18790.1 & AT1G09570.1 & 0.781 \\
\hline PHYB & PIF3 & AT2G18790.1 & AT1G09530.2 & 0.999 \\
\hline PHYB & TOC1 & AT2G18790.1 & AT5G61380.1 & 0.832 \\
\hline PIF3 & LHY & AT1G09530.2 & AT1G01060.2 & 0.665 \\
\hline PIF3 & PHYA & AT1G09530.2 & AT1G09570.1 & 0.998 \\
\hline PIF3 & PHYB & AT1G09530.2 & AT2G18790.1 & 0.999 \\
\hline PIF3 & TOC1 & AT1G09530.2 & AT5G61380.1 & 0.91 \\
\hline STZ & APX1 & AT1G27730.1 & AT1G07890.8 & 0.58 \\
\hline STZ & JAZ1 & AT1G27730.1 & AT1G19180.1 & 0.791 \\
\hline STZ & JAZ5 & AT1G27730.1 & AT1G17380.1 & 0.41 \\
\hline STZ & MPK11 & AT1G27730.1 & AT1G01560.2 & 0.417 \\
\hline STZ & MYC2 & AT1G27730.1 & AT1G32640.1 & 0.635 \\
\hline TGA6 & COI1 & AT3G12250.4 & AT2G39940.1 & 0.461 \\
\hline TGA6 & MYC2 & AT3G12250.4 & AT1G32640.1 & 0.522 \\
\hline TOC1 & LHY & AT5G61380.1 & AT1G01060.2 & 0.995 \\
\hline TOC1 & PHYA & AT5G61380.1 & AT1G09570.1 & 0.795 \\
\hline TOC1 & PHYB & AT5G61380.1 & AT2G18790.1 & 0.832 \\
\hline TOC1 & PIF3 & AT5G61380.1 & AT1G09530.2 & 0.91 \\
\hline Total & & & & 65 \\
\hline
\end{tabular}


Table S2: Artemisia annua L. EST contigs involved in different Biological process

\begin{tabular}{|c|c|c|c|c|c|c|c|c|c|}
\hline Source & $\begin{array}{c}\text { Term_- } \\
\text { name }\end{array}$ & $\begin{array}{c}\text { Term } \\
\text { id }\end{array}$ & $\begin{array}{c}\text { Adjusted_p_v } \\
\text { alue }\end{array}$ & $\begin{array}{c}\text { Negative_log10_of_- } \\
\text { adjusted_p_value }\end{array}$ & $\begin{array}{c}\text { Term } \\
\text { size }\end{array}$ & $\begin{array}{c}\text { Query } \\
\text { size }\end{array}$ & $\begin{array}{l}\text { Intersection } \\
\text { size }\end{array}$ & $\begin{array}{c}\text { Effective_ } \\
\text { domain_size }\end{array}$ & Intersections \\
\hline GO:MF & $\begin{array}{l}\text { DNA-binding } \\
\text { transcription } \\
\text { factor activity }\end{array}$ & GO:0003700 & \begin{tabular}{|l|}
0.048997503 \\
\end{tabular} & 1.309826048 & 1634 & 23 & 8 & 20815 & $\begin{array}{l}\text { "AT1G49720.1,AT5G03790.1,AT1G09530.1,AT1G01060.1,AT1G27730.1,AT3G12250.1,AT1 } \\
\text { G59750.1,AT1G04370.1" }\end{array}$ \\
\hline GO:BP & $\begin{array}{l}\text { response to } \\
\text { hormone }\end{array}$ & GO:0009725 & $1.16 \mathrm{E}-07$ & 6.936801322 & 1858 & 23 & 14 & 22991 & $\begin{array}{l}\text { "AT1G49720.1,AT1G09530.1,AT1G01060.1,AT1G27730.1,AT2G05710.1,AT1G17380.1,AT1 } \\
\text { G19180.1,AT1G07890.1,AT2G17290.1,AT1G59750.1,AT1G15550.1,AT1G04370.1,AT1G482 } \\
\text { 70.1,AT1G01560.2" }\end{array}$ \\
\hline GO:BP & $\begin{array}{l}\text { response to } \\
\text { endogenous } \\
\text { stimulus }\end{array}$ & GO:0009719 & $1.50 \mathrm{E}-07$ & 6.822830639 & 1895 & 23 & 14 & 22991 & $\begin{array}{l}\text { "AT1G49720.1,AT1G09530.1,AT1G01060.1,AT1G27730.1,AT2G05710.1,AT1G17380.1,AT1 } \\
\text { G19180.1,AT1G07890.1,AT2G17290.1,AT1G59750.1,AT1G15550.1,AT1G04370.1,AT1G482 } \\
\text { 70.1,AT1G01560.2" }\end{array}$ \\
\hline GO:BP & $\begin{array}{l}\text { response to } \\
\text { acid chemical }\end{array}$ & GO:0001101 & $6.28 \mathrm{E}-07$ & 6.201992171 & 1338 & 23 & 12 & 22991 & $\begin{array}{l}\text { "AT1G49720.1,AT1G09530.1,AT1G01060.1,AT1G277301,AT2G05710.1,AT1G17380.1,AT1 } \\
\text { G19180.1,AT1G01470.1,AT2G17290.1,AT1G15550.1,AT1G48270.1,AT1G01560.2" }\end{array}$ \\
\hline GO:BP & $\begin{array}{l}\text { response to } \\
\text { chemical }\end{array}$ & GO:0042221 & $1.05759 \mathrm{E}-06$ & 5.97568246 & 3203 & 23 & 16 & 22991 & $\begin{array}{l}\text { "AT1G49720.1,AT1G09530.1,AT1G01060.1,AT1G27730.1,AT2G05710.1,AT1G17380.1,AT1 } \\
\text { G19180.1,AT3G12250.1,AT1G07890.1,AT1G01470.1,AT2G17290.1,AT1G59750.1,AT1G155 } \\
\text { 50.1,AT1G04370.1,AT1G48270.1,AT1G01560.2" }\end{array}$ \\
\hline GO:BP & $\begin{array}{l}\begin{array}{l}\text { response to } \\
\text { organic } \\
\text { substance }\end{array} \\
\end{array}$ & GO:0010033 & $1.10979 \mathrm{E}-06$ & 5.954758443 & 2204 & 23 & 14 & 22991 & $\begin{array}{l}\text { "AT1G49720.1,AT1G09530.1,AT1G01060.1,AT1G27730.1,AT2G05710.1,AT1G17380.1,AT1 } \\
\text { G19180.1,AT1G07890.1,AT2G17290.1,AT1G59750.1,AT1G15550.1,AT1G04370.1,AT1G482 } \\
\text { 70.1,AT1G01560.2" }\end{array}$ \\
\hline GO:BP & $\begin{array}{l}\text { response to } \\
\text { oxygen- } \\
\text { containing } \\
\text { compound }\end{array}$ & GO:1901700 & $1.14646 \mathrm{E}-06$ & 5.94064165 & 1785 & 23 & 13 & 22991 & $\begin{array}{l}\text { "AT1G49720.1,AT1G09530.1,AT1G01060.1,AT1G27730.1,AT2G05710.1,AT1G17380.1,AT1 } \\
\text { G19180.1,AT1G07890.1,AT1G01470.1,AT2G17290.1,AT1G15550.1,AT1G48270.1,AT1G015 } \\
\text { 60.2" }\end{array}$ \\
\hline GO:BP & $\begin{array}{l}\text { response to } \\
\text { lipid }\end{array}$ & GO:0033993 & $4.20496 \mathrm{E}-05$ & 4.376238029 & 862 & 23 & 9 & 22991 & $\begin{array}{l}\text { "AT1G49720.1,AT1G09530.1,AT1G01060.1,AT1G27730.1,AT2G05710.1,AT2G17290.1,AT1 } \\
\text { G15550.1,AT1G48270.1,AT1G01560.2" }\end{array}$ \\
\hline GO:BP & $\begin{array}{l}\text { response to } \\
\text { stimulus }\end{array}$ & GO:0050896 & \begin{tabular}{|l}
$5.85787 \mathrm{E}-05$ \\
\end{tabular} & 4.232260367 & 6521 & 23 & 19 & 22991 & $\begin{array}{l}\text { "AT1G49720.1,AT1G09530.1,AT1G01060.1,AT1G27730.1,AT2G05710.1,AT1G17380.1,AT1 } \\
\text { G19180.1,AT3G12250.1,AT1G07890.1,AT1G01470.1,AT1G01120.1,AT2G17290.1,AT1G597 } \\
\text { 50.1,AT1G15550.1,AT1G04370.1,AT3G54840.1,AT1G02400.1,AT1G48270.1,AT1G01560.2" }\end{array}$ \\
\hline GO:BP & $\begin{array}{l}\text { hormone- } \\
\text { mediated } \\
\text { signaling } \\
\text { pathway }\end{array}$ & GO:0009755 & \begin{tabular}{|c|}
$7.60765 \mathrm{E}-05$ \\
\end{tabular} & 4.118749685 & 924 & 23 & 9 & 22991 & $\begin{array}{l}\text { "AT1G49720.1,AT1G09530.1,AT1G17380.1,AT1G19180.1,AT2G17290.1,AT1G59750.1,AT1 } \\
\text { G15550.1,AT1G04370.1,AT1G48270.1" }\end{array}$ \\
\hline GO:BP & $\begin{array}{l}\text { cellular } \\
\text { response to } \\
\text { hormone } \\
\text { stimulus }\end{array}$ & GO:0032870 & \begin{tabular}{|l|}
0.000224864 \\
\end{tabular} & 3.648079812 & 1050 & 23 & 9 & 22991 & $\begin{array}{l}\text { "AT1G49720.1,AT1G09530.1,AT1G17380.1,AT1G19180.1,AT2G17290.1,AT1G59750.1,AT1 } \\
\text { G15550.1,AT1G04370.1,AT1G48270.1" }\end{array}$ \\
\hline GO:BP & $\begin{array}{l}\text { response to } \\
\text { light stimulus }\end{array}$ & GO:0009416 & \begin{tabular}{|l|}
0.000240227 \\
\end{tabular} & 3.61937837 & 754 & 23 & 8 & 22991 & $\begin{array}{l}\text { "AT1G09530.1,AT1G01060.1,AT1G27730.1,AT1G01470.1,AT1G01120.1,AT1G15550.1,AT1 } \\
\text { G02400.1,AT1G48270.1" }\end{array}$ \\
\hline GO:BP & $\begin{array}{l}\text { response to } \\
\text { radiation }\end{array}$ & GO:0009314 & \begin{tabular}{|l|}
0.000301691 \\
\end{tabular} & 3.520438356 & 777 & 23 & 8 & 22991 & $\begin{array}{l}\text { "AT1G09530.1,AT1G01060.1,AT1G27730.1,AT1G01470.1,AT1G01120.1,AT1G15550.1,AT1 } \\
\text { G02400.1,AT1G48270.1" }\end{array}$ \\
\hline GO:BP & \begin{tabular}{|l} 
cellular \\
response to \\
endogenous \\
stimulus
\end{tabular} & GO:0071495 & \begin{tabular}{|l|}
0.000305754 \\
\end{tabular} & 3.514627674 & 1089 & 23 & 9 & 22991 & $\begin{array}{l}\text { "AT1G49720.1,AT1G09530.1,AT1G17380.1,AT1G19180.1,AT2G17290.1,AT1G59750.1,AT1 } \\
\text { G15550.1,AT1G04370.1,AT1G48270.1" }\end{array}$ \\
\hline GO:BP & $\begin{array}{l}\text { cellular } \\
\text { response to } \\
\text { chemical } \\
\text { stimulus }\end{array}$ & GO:0070887 & \begin{tabular}{|l}
0.000464428 \\
\end{tabular} & 3.333081169 & 1518 & 23 & 10 & 22991 & $\begin{array}{l}\text { "AT1G49720.1,AT1G09530.1,AT1G17380.1,AT1G19180.1,AT1G07890.1,AT2G17290.1,AT1 } \\
\text { G59750.1,AT1G15550.1,AT1G04370.1,AT1G48270.1" }\end{array}$ \\
\hline GO:BP & \begin{tabular}{|l} 
cellular \\
response to \\
organic \\
substance
\end{tabular} & GO:0071310 & \begin{tabular}{|l|}
0.000647609 \\
\end{tabular} & 3.18868723 & 1191 & 23 & 9 & 22991 & $\begin{array}{l}\text { "AT1G49720.1,AT1G09530.1,AT1G17380.1,AT1G19180.1,AT2G17290.1,AT1G59750.1,AT1 } \\
\text { G15550.1,AT1G04370.1,AT1G48270.1" }\end{array}$ \\
\hline GO:BP & $\begin{array}{l}\text { signal } \\
\text { transduction }\end{array}$ & GO:0007165 & \begin{tabular}{|l|}
0.000777896 \\
\end{tabular} & 3.109078332 & 2045 & 23 & 11 & 22991 & $\begin{array}{l}\text { "AT1G49720.1,AT1G09530.1,AT1G17380.1,AT1G19180.1,AT2G17290.1,AT1G59750.1,AT1 } \\
\text { G15550.1,AT1G04370.1,AT3G54840.1,AT1G48270.1,AT1G01560.2" }\end{array}$ \\
\hline GO:BP & $\begin{array}{l}\text { cellular } \\
\text { response to } \\
\text { acid chemical }\end{array}$ & GO:0071229 & \begin{tabular}{|l|}
0.000798042 \\
\end{tabular} & 3.097974508 & 600 & 23 & 7 & 22991 & $\begin{array}{l}\text { "AT1G49720.1,AT1G09530.1,AT1G17380.1,AT1G19180.1,AT2G17290.1,AT1G15550.1,AT1 } \\
\text { G48270.1" }\end{array}$ \\
\hline GO:BP & \begin{tabular}{|l|} 
signaling \\
\end{tabular} & GO:0023052 & \begin{tabular}{|l|}
0.000947917 \\
\end{tabular} & 3.023229885 & 2086 & 23 & 11 & 22991 & $\begin{array}{l}\text { "AT1G49720.1,AT1G09530.1,AT1G17380.1,AT1G19180.1,AT2G17290.1,AT1G59750.1,AT1 } \\
\text { G15550.1,AT1G04370.1,AT3G54840.1,AT1G48270.1,AT1G01560.2" }\end{array}$ \\
\hline GO:BP & $\begin{array}{l}\text { response to } \\
\text { abscisic acid }\end{array}$ & GO:0009737 & 0.00123854 & 2.907089943 & 641 & 23 & 7 & 22991 & $\begin{array}{l}\text { "AT1G49720.1,AT1G01060.1,AT1G27730.1,AT2G05710.1,AT2G17290.1,AT1G48270.1,AT1 } \\
\text { G01560.2" }\end{array}$ \\
\hline GO:BP & $\begin{array}{l}\text { response to } \\
\text { alcohol }\end{array}$ & GO:0097305 & \begin{tabular}{|l|}
0.001290722 \\
\end{tabular} & 2.889167267 & 645 & 23 & 7 & 22991 & $\begin{array}{l}\text { "AT1G49720.1,AT1G01060.1,AT1G27730.1,AT2G05710.1,AT2G17290.1,AT1G48270.1,AT1 } \\
\text { G01560.2" }\end{array}$ \\
\hline GO:BP & $\begin{array}{l}\text { response to } \\
\text { abiotic } \\
\text { stimulus }\end{array}$ & GO:0009628 & \begin{tabular}{|l|}
0.001352113 \\
\end{tabular} & 2.868986876 & 2162 & 23 & 11 & 22991 & $\begin{array}{l}\text { "AT1G09530.1,AT1G01060.1,AT1G27730.1,AT2G05710.1,AT1G19180.1,AT1G07890.1,AT1 } \\
\text { G01470.1,AT1G01120.1,AT1G15550.1,AT1G02400.1,AT1G48270.1" }\end{array}$ \\
\hline GO:BP & \begin{tabular}{|l|} 
cell \\
communicatio \\
$\mathrm{n}$
\end{tabular} & GO:0007154 & \begin{tabular}{|c|}
0.002886871 \\
\end{tabular} & 2.539572632 & 2335 & 23 & 11 & 22991 & $\begin{array}{l}\text { "AT1G49720.1,AT1G09530.1,AT1G17380.1,AT1G19180.1,AT2G17290.1,AT1G59750.1,AT1 } \\
\text { G15550.1,AT1G04370.1,AT3G54840.1,AT1G48270.1,AT1G01560.2" }\end{array}$ \\
\hline GO:BP & \begin{tabular}{|l|} 
cellular \\
response to \\
oxygen- \\
containing \\
compound
\end{tabular} & GO:1901701 & \begin{tabular}{|l|}
0.005729766 \\
\end{tabular} & 2.241863141 & 809 & 23 & 7 & 22991 & $\begin{array}{l}\text { "AT1G49720.1,AT1G09530.1,AT1G17380.1,AT1G19180.1,AT2G17290.1,AT1G15550.1,AT1 } \\
\text { G48270.1" }\end{array}$ \\
\hline GO:BP & $\begin{array}{l}\text { biological } \\
\text { regulation }\end{array}$ & GO:0065007 & \begin{tabular}{|l|}
0.007985836 \\
\end{tabular} & 2.097679619 & 6776 & 23 & 17 & 22991 & $\begin{array}{l}\text { "AT1G49720.1,AT5G03790.1,AT1G09530.1,AT1G01060.1,AT1G27730.1,AT1G17380.1,AT1 } \\
\text { G19180.1,AT3G12250.1,AT2G17290.1,AT1G59750.1,AT1G15550.1,AT1G04370.1,AT3G548 } \\
\text { 40.1,AT1G02400.1,AT1G48270.1,AT1G01560.2,AT1G30450.1" }\end{array}$ \\
\hline GO:BP & $\begin{array}{l}\text { cellular } \\
\text { response to } \\
\text { stimulus }\end{array}$ & GO:0051716 & \begin{tabular}{|l|}
0.009547462 \\
\end{tabular} & 2.020112062 & 3211 & 23 & 12 & 22991 & $\begin{array}{l}\text { "AT1G49720.1,AT1G09530.1,AT1G17380.1,AT1G19180.1,AT1G07890.1,AT2G17290.1,AT1 } \\
\text { G59750.1,AT1G15550.1,AT1G04370.1,AT3G54840.1,AT1G48270.1,AT1G01560.2" }\end{array}$ \\
\hline GO:BP & $\begin{array}{l}\text { response to } \\
\text { gibberellin }\end{array}$ & GO:0009739 & 0.010876545 & 1.963509037 & 161 & 23 & 4 & 22991 & "AT1G09530.1,AT1G01060.1,AT1G15550.1,AT1G48270.1" \\
\hline GO:BP & $\begin{array}{l}\text { regulation of } \\
\text { cellular } \\
\text { process }\end{array}$ & GO:0050794 & \begin{tabular}{|l}
0.011024477 \\
\end{tabular} & 1.957641991 & 5289 & 23 & 15 & 22991 & $\begin{array}{l}\text { "AT1G49720.1,AT5G03790.1,AT1G09530.1,AT1G01060.1,AT1G27730.1,AT1G17380.1,AT1 } \\
\text { G19180.1,AT3G12250.1,AT2G17290.1,AT1G59750.1,AT1G15550.1,AT1G04370.1,AT3G548 } \\
\text { 40.1,AT1G48270.1,AT1G01560.2" }\end{array}$ \\
\hline GO:BP & $\begin{array}{l}\text { response to } \\
\text { wounding }\end{array}$ & GO:0009611 & 0.026945217 & 1.569518317 & 203 & 23 & 4 & 22991 & "AT1G27730.1,AT1G17380.1,AT1G19180.1,AT1G01470.1" \\
\hline GO:BP & \begin{tabular}{|l|} 
gibberellic \\
acid mediated \\
signaling \\
pathway
\end{tabular} & GO:0009740 & \begin{tabular}{|l|}
0.040192429 \\
\end{tabular} & 1.395855751 & 80 & 23 & 3 & 22991 & "AT1G09530.1,AT1G15550.1,AT1G48270.1" \\
\hline
\end{tabular}


Role of ESTs in Abiotic signaling in A. annua L.

\begin{tabular}{|c|c|c|c|c|c|c|c|c|c|}
\hline GO:BP & $\begin{array}{l}\text { gibberellin } \\
\text { mediated } \\
\text { signaling } \\
\text { pathway }\end{array}$ & GO:0010476 & 0.041711076 & 1.37974861 & 81 & 23 & 3 & 22991 & "AT1G09530.1,AT1G15550.1,AT1G48270.1" \\
\hline GO:BP & \begin{tabular}{|l|} 
cellular \\
response to \\
gibberellin \\
stimulus \\
\end{tabular} & GO:0071370 & 0.046491195 & 1.332629287 & 84 & 23 & 3 & 22991 & "AT1G09530.1,AT1G15550.1,AT1G48270.1" \\
\hline GO:BP & $\begin{array}{l}\text { regulation of } \\
\text { biological } \\
\text { process }\end{array}$ & GO:0050789 & 0.049742196 & 1.303275048 & 5957 & 23 & 15 & 22991 & $\begin{array}{l}\text { "AT1G49720.1,AT5G03790.1,AT1G09530.1,AT1G01060.1,AT1G27730.1,AT1G17380.1,AT1 } \\
\text { G19180.1,AT3G12250.1,AT2G17290.1,AT1G59750.1,AT1G15550.1,AT1G04370.1,AT3G548 } \\
\text { 40.1,AT1G48270.1,AT1G01560.2" }\end{array}$ \\
\hline GO:CC & $\begin{array}{l}\text { intracellular } \\
\text { part }\end{array}$ & GO:0044424 & 0.019838978 & 1.702480706 & 13817 & 22 & 22 & 20312 & $\begin{array}{l}\text { "AT1G49720.1,AT5G03790.1,AT1G09530.1,AT1G01780.1,AT1G01060.1,AT1G27730.1,AT1 } \\
\text { G05000.1,AT2G05710.1,AT1G17380.1,AT1G19180.1,AT3G12250.1,AT1G07890.1,AT1G014 } \\
\text { 70.1,AT1G01120.1,AT2G17290.1,AT1G59750.1,AT1G15550.1,AT1G04370.1,AT3G54840.1, } \\
\text { AT1G48270.1,AT1G01560.2,AT1G30450.1" }\end{array}$ \\
\hline GO:CC & intracellular & GO:0005622 & 0.026630365 & 1.574622875 & 14003 & 22 & 22 & 20312 & $\begin{array}{l}\text { "AT1G49720.1,AT5G03790.1,AT1G09530.1,AT1G01780.1,AT1G01060.1,AT1G27730.1,AT1 } \\
\text { G05000.1,AT2G05710.1,AT1G17380.1,AT1G19180.1,AT3G12250.1,AT1G07890.1,AT1G014 } \\
\text { 70.1,AT1G01120.1,AT2G17290.1,AT1G59750.1,AT1G15550.1,AT1G04370.1,AT3G54840.1, } \\
\text { AT1G48270.1,AT1G01560.2,AT1G30450.1" }\end{array}$ \\
\hline KEGG & $\begin{array}{l}\text { Plant hormone } \\
\text { signal } \\
\text { transduction }\end{array}$ & KEGG:04075 & 0.000820171 & 3.086095731 & 273 & 13 & 6 & 4851 & "AT1G49720.1,AT1G09530.1,AT1G17380.1,AT1G19180.1,AT3G12250.1,AT1G59750.1" \\
\hline KEGG & $\begin{array}{l}\begin{array}{l}\text { Diterpenoid } \\
\text { biosynthesis }\end{array} \\
\end{array}$ & KEGG:00904 & 0.03302247 & 1.481190451 & 22 & 13 & 2 & 4851 & "AT1G15550.1,AT1G02400.1" \\
\hline
\end{tabular}

